\title{
O POSICIONAMENTO DOS PARLAMENTARES DO PARTIDO DOS TRABALHADORES SOBRE A REFORMA AGRÁRIA NA DÉCADA DE 1990: OMISSÕES, PROPOSTAS E VIOLÊNCIAS
}

Glauber Eduardo Ribeiro Cruz ${ }^{l}$ Priscila Carlos Brandão

Resumo: O objetivo do texto é apresentar como os deputados federais do Partido dos Trabalhadores, que atuaram na temática da reforma agrária, na década de 1990 lutaram pela sua implantação a nível nacional. Para isso, a fonte principal são os discursos disponibilizados no site da Câmara dos Deputados. Na perspectiva metodológica, o discurso político é o instante privilegiado para a ação política, em meio aos fatos e aos acontecimentos, e como objeto de pesquisa requer a necessidade de serem mapeados em regularidades, em séries, em saberes, em temas e em conceitos, para localizar a construção de imagens de si e dos outros, as lutas políticas e as batalhas discursivas. Os discursos dos parlamentares petistas consolidaram suas carreiras políticas por meio da bandeira da reforma agrária: propondo projetos de lei, criticando as propostas e as ações dos governos federais para protelar, minimizar a importância do tema e diminuir a responsabilidade do Estado na questão de terras no país e participando de comissões de estudos para a consolidação do tema da reforma agrária como especificidades e singularidades como atores políticos do PT e como questão fundamental para os trabalhadores do campo no país.

Palavras-chave: Partido dos Trabalhadores; Parlamentares; discurso político: Reforma agrária; Trabalhadores do campo.

\footnotetext{
${ }^{1}$ Mestre em História pela Universidade Federal de Minas Gerais (UFMG) com a dissertação A identidade e a carreira parlamentar do Partido dos Trabalhadores nos discursos dos deputados federais e senadores (1983-2006). Docente do Estado de Minas Gerais. glaubereduardoribeirocruz@gmail.com

2Atualmente é líder do Diretório de Pesquisa do Cnpq “Inteligência Governamental”, coordenadora do Centro de Estudos de Inteligência Governamental da UFMG, em um trabalho interinstitucional, desenvolvido em parceria com vários profissionais da área de inteligência governamental e membro da Junta Diretora da Rec Latinomediterranea de Inteligencia, com sede em Cádiz, Espanha
}

Abstract: The aim of the paper is to present to the deputies of the Workers Party, which worked on the theme of agrarian reform, in the 1990s fought for implementation of agrarian reform, the national level. For this, the main source is the speeches made available on the websites of the Chamber of Deputies. The methodological perspective, the political discourse is the privileged moment for political action, among the facts and events, and as a research subject requires the need to be mapped into regularities in series, in knowledge, in themes and concepts, to locate the construction of images of themselves and others, struggles discursive and political battles. The speeches of the PT parliamentarians consolidated their political careers trough the banner of agrarian reform: proposing bills, criticizing the proposals and actions of the federal government to delay, minimize the importance of the issue and reduce the state's responsability in the land question in the country and participating in committees of studies for the consolidation of the issue of land reform as specificities and singularities as policial actors and the PT as a key issue for rural workers in the country.

Keywords: Workers Party; parliamentarians; Political speech; Agrarian reform; Rural workers.

\section{Introdução}

A questão agrária no Brasil na década de 1990 está diretamente relacionada aos direitos sociais presentes na Constituição Federal de 1988. Junto a luta pela terra, o salário mínimo e a previdência social podem ser incluídos nos direitos sociais defendidos pelo Partido dos Trabalhadores nos anos de 1990. Por meio da luta institucional, os deputados federais do Partido dos Trabalhadores defenderam uma perspectiva social, baseada principalmente na regulamentação das leis implantadas na Constituição Federal, e os deputados governistas lutaram incessantemente pela implantação do neoliberalismo no país, representado por meio das propostas de desregulamentação das leis direcionadas para a área social.

As fontes utilizadas no texto são: os discursos dos deputados federais do Partido dos Trabalhadores (PT) localizados no Diário do Congresso Nacional (1990-1995) e no Diário da Câmara dos Deputados (1995-1998) e encontrados no site oficial da Câmara dos Deputados. O uso dos discursos se justifica pela importância dos registros realizados e pelo próprio ineditismo, uma vez que nas diversas leituras realizadas envolvendo pesquisa sobre o Partido dos Trabalhadores, não foi identificado nenhum autor/autora que 
deles tenha se utilizado como objeto de análise.

Os poucos estudiosos que se dispuseram a examinar o partido sob a ótica dos seus parlamentares, tentando preencher lacunas sobre a atuação congressual e a relação entre a estrutura partidária e o mandato parlamentar foram de Ana Lúcia Aguiar Melo (1998), Paulo Roberto Figueira Leal (2005), e Sônia Ranincheski, e Nathália Cordeiro (2008).

As fontes partidárias também serão importantes como referência bibliográfica e instrumento ideológico e político de unificação partidária. Porém, é necessário realizar considerações sobre seus alcances e limites:

Nem sempre explicitam, por exemplo, o contexto político e social em que foram produzidas; quase nunca colocam à mostra o rico $\mathrm{e}$ variado debate que os envolveu; são, em geral, ufanistas em relação às possibilidades reais do PT; por fim, o que é particularmente importante do ponto de vista da relação entre teoria e prática, raramente avaliam os contrastes e as concordâncias das resoluções anteriores em relação à realidade existente e à prática partidária (RESOLUÇÕES DE ENCONTROS E CONGRESSOS, 1998, p. 18).

Neste ponto, consideramos que a atividade partidária desenvolvida nas instituições políticas foi praticada no plenário do Congresso Nacional, pois se trata do locus privilegiado de divulgação, definição e construção da concepção de política e da sociedade de cada partido político. A atividade parlamentar e o discurso são elementos necessários para a conquista de apoio e para o desenvolvimento de paixão política.

\section{A proposta metodológica: uma reflexão sobre a análise}

\section{de discurso}

Na perspectiva metodológica, a análise de discurso foi o método escolhido para o exame das fontes utilizadas. A análise do discurso e do pensamento político é importante para identificar as ações e os fatos que reagem ao passado, modificam o presente, e criam o futuro. Para se trabalhar com os discursos procura-se apresentá-los como atividade e continuidade de ação, por meio de performances, sendo um "campo de estudos constituído por atos de discurso, sejam eles orais, manuscritos ou impressos, e pelas condições ou contextos em que esses atos foram emitidos" (POCOCK, 2003, p. 64).

$\mathrm{O}$ discurso e o debate político como fontes da história são relevantes a partir da variedade das linguagens políticas, dos atores e dos contextos históricos, lingüísticos e políticos. Os critérios constituintes da linguagem como fonte histórica são as construções, os acontecimentos e os valores sociais reconhecidos na performance discursiva, sendo o discurso político prático e animado por necessidades do presente: "a situação prática incluirá pressões, restrições e encorajamentos aos quais o autor estava sujeito ou acreditava estar sujeito, originados nas preferências e antipatias de terceiros e nas limitações e oportunidades do contexto político, tal como ele o percebia ou vivia" (POCOCK, 2003, p. 39).

O discurso utilizado no plenário da Câmara dos Deputados deve revelar a continuidade e a mudança, onde devemos reconhecer a consistência de paradigmas e uma multiplicidade de performances e de agentes que constroem a identidade e a carreira parlamentar por meio da experiência política. O discurso pode causar abalos e agitações, constituindo-se no instante privilegiado para a ação política, em meio aos fatos e aos acontecimentos, e "certamente devemos estudar as transformações no discurso na medida em que elas geram transformações na prática, mas há sempre um intervalo no tempo, suficiente para gerar heterogeneidade no efeito" (POCOCK, 2003, p. 82).

Há necessidade de conceber os discursos e os pronunciamentos como fontes que se justificam por serem conceitos polissêmicos, como afirma Durval Muniz de Albuquerque Junior (2009).

Quando falar aqui de discursos, estarei me referindo a uma peça oratória proferida em público ou escrita como se fosse para ser lida para um dado público. Estarei me referindo a uma fala ou oração feita para dada audiência, podendo ser escrita previamente ou dita de improviso, tendo ficado registrada de alguma forma, seja através da memória daqueles que a ouviram ou presenciaram, seja através de sua versão original, quando por escrito, seja através de sua reprodução, veiculação e repercussão através de distintos meios de comunicação social: o jornal, a revista, o rádio, a televisão, o cinema, a internet, a fotografia etc. (ALBUQUERQUE JUNIOR, 2009, p. 223-224).

Nesta perspectiva, a análise do discurso está no lugar social³: a própria

Encarar os discursos como monumentos é examiná-los, e "eles se tornam a matéria mesma da análise do historiador, que descobre que todos os documentos ou testemunhos são formas de discurso, que os objetos e sujeitos não preexistem aos discursos que deles falam, mas são constituídos por eles" (ALBUQUERQUE JUNIOR, 2009, p. 235). 
produção, a época, em quais circunstâncias políticas, econômicas e sociais, por quem, como e o que ele diz sobre o passado construindo sua historicidade por meio da análise externa e interna.

A análise externa requer o contexto, as condições históricas que permitiram sua emergência, datação e localização espacial, autoria e momento histórico, circunstâncias, pretexto, situação e objetivos. Por sua vez, a análise interna exige interrogar-se sobre a ordem do discurso e da formação discursiva, obedecendo regras gramaticais e estrutura da língua e modelos de gêneros narrativos. Albuquerque Júnior (2009) afirma que a utilização dos discursos como objeto de pesquisa requer a necessidade de serem mapeados em regularidades, em séries, em saberes, em temas e em conceitos, para localizar a construção de imagens de si e dos outros, as lutas políticas e as batalhas discursivas, e "é indispensável que estes discursos e pronunciamentos sejam cotejados com outros tipos de fontes e com discursos vindos de outros personagens do período, envolvidos com os mesmos episódios ou dentro do mesmo universo de preocupações" (ALBUQUERQUE JUNIOR, 2009, p. 243).

Na nossa proposta teórica e metodológica, os discursos sobre a temática da reforma agrária serão considerados como elementos identitários dos deputados federais petistas selecionados entre os anos de 1990 e 1998, tempo curto, porém necessário para perceber com regularidade nos discursos dos parlamentares do Partido dos Trabalhadores a luta e a defesa pela reforma agrária. Concomitantemente, tenta-se perceber como os parlamentares governistas agiram e reagiram aos discursos proferidos pelos oposicionistas sobre a reforma agrária. Os discursos proferidos na atividade partidária se consolidam como fonte de inspiração, paixão e consciência para a consolidação de um grupo, dando-lhes uma identidade política.

\section{Os deputados federais do Partido dos Trabalhadores:}

\section{a defesa da reforma agrária}

O texto abaixo é uma parte da dissertação de mestrado defendida no Programa de Pós-Graduação da Universidade Federal de Minas Gerais no ano de 2014. Neste trabalho denominado Identidade e carreira parlamentar do Partido dos Trabalhadores nos discursos dos deputados federais e senadores (1983-2006) identifiquei doze parlamentares que construíram suas carreiras políticas na Câmara dos Deputados e no Senado Federal por meio de temáticas específicas, dentre as quais está presente a reforma agrária.
Neste ponto é necessário esclarecer o que denomino de carreira política: são deputados federais ou senadores que têm mais de dezesseis anos como parlamentar, tempo importante para ter construído e desenvolvido temáticas abrangentes e defendido ideias políticas. Ainda, consegui localizar quatro deputados federais que lutaram, praticamente por durante toda a década de 1990, pela causa da reforma agrária: Paulo Rocha, Adão Pretto, Paulo Paim e Fernando Ferro. Destes, Rocha, Pretto e Ferro têm um histórico com os movimentos de luta pela terra no Brasil. Paim tem um forte vínculo com os movimentos sociais, principalmente, os sindicatos. Este parlamentar tem a luta política mais enraizada com foco na questão do salário mínimo.

A seguir apresento os nomes, os anos e os mandatos dos deputados federais acima citados:

\begin{tabular}{|l|l|l|}
\hline Deputados federais & Anos & Mandatos \\
\hline Paulo Renato Paim & $\begin{array}{l}1986,1990,1994,1998 \\
2002^{*}, 2010^{*}\end{array}$ & Quatro \\
\hline Fernando Dantas Ferro & $1994,1998,2002,2006$ & Quatro \\
\hline Paulo Roberto Galvão da Rocha & $\begin{array}{l}1990,1994,1998,2002, \\
2006\end{array}$ & Cinco \\
\hline Adão Pretto & $\begin{array}{l}1990,1994,1998,2002, \\
2006\end{array}$ & Cinco \\
\hline
\end{tabular}

Fonte: Dados fornecidos pelo Tribunal Superior Eleitoral.

* Anos em que o parlamentar foi eleito senador.

Os discursos dos deputados federais do Partido dos Trabalhadores entre os anos de 1990 e 1998 sobre o tema da reforma agrária totalizam 421. Destes, os parlamentares escolhidos para análise, tem a participação em 391, ou seja, mais de $90 \%$ dos discursos pronunciados na Câmara dos Deputados. Abaixo segue as tabelas referentes aos quatro parlamentares, os anos dos pronunciamentos e a quantidade de discursos.

Os discursos têm a reforma agrária como tema principal, e como temas específicos, aparecem às omissões dos governos federais e estaduais, as propostas do Partido dos Trabalhadores e dos parlamentares para a realização da reforma agrária no país e a violência causada pela polícia militar nos estados com o apoio de políticos, juízes e técnicos. 


\begin{tabular}{|c|c|c|}
\hline Deputado Federal & Anos & Quantidade \\
\hline \multirow{4}{*}{ Paulo Paim } & 1990 & 1 \\
\cline { 2 - 3 } & 1991 & 1 \\
\cline { 2 - 3 } & 1992 & 0 \\
\cline { 2 - 3 } & 1993 & 1 \\
\cline { 2 - 3 } & 1994 & 0 \\
\cline { 2 - 3 } & 1995 & 0 \\
\cline { 2 - 3 } & 1996 & 8 \\
\cline { 2 - 3 } & 1997 & 0 \\
\cline { 2 - 3 } & 1998 & 14 \\
\hline
\end{tabular}

\begin{tabular}{|c|c|c|}
\hline Deputado Federal & Anos & Quantidade \\
\hline \multirow{4}{*}{ Fernando Ferro } & 1995 & 7 \\
\cline { 2 - 3 } & 1996 & 14 \\
\cline { 2 - 3 } & 1997 & 20 \\
\cline { 2 - 3 } & 1998 & 12 \\
\cline { 2 - 3 } & Total & 53 \\
\hline
\end{tabular}

\begin{tabular}{|c|c|c|}
\hline Deputado Federal & Anos & Quantidade de discursos \\
\hline \multirow{4}{*}{ Paulo Rocha } & 1990 & 0 \\
\cline { 2 - 3 } & 1991 & 2 \\
\cline { 2 - 3 } & 1992 & 3 \\
\cline { 2 - 3 } & 1993 & 4 \\
\cline { 2 - 3 } & 1994 & 2 \\
\cline { 2 - 3 } & 1995 & 19 \\
\cline { 2 - 3 } & 1996 & 35 \\
\cline { 2 - 3 } & 1997 & 31 \\
\cline { 2 - 3 } & 1998 & 14 \\
\hline
\end{tabular}

\begin{tabular}{|c|c|c|}
\hline Deputado Federal & Anos & Quantidade de discursos \\
\hline \multirow{4}{*}{ Adão Pretto } & 1990 & 0 \\
\cline { 2 - 3 } & 1991 & 26 \\
\cline { 2 - 3 } & 1992 & 25 \\
\cline { 2 - 3 } & 1993 & 18 \\
\cline { 2 - 3 } & 1994 & 5 \\
\cline { 2 - 3 } & 1995 & 24 \\
\cline { 2 - 3 } & 1996 & 51 \\
\cline { 2 - 3 } & 1997 & 45 \\
\cline { 2 - 3 } & 1998 & 20 \\
\hline \multirow{5}{*}{} & Total & 214 \\
\hline
\end{tabular}

Assim, os discursos utilizados abaixo são relevantes porque neles estão contidas as principais propostas partidárias e parlamentares, as críticas mais contundentes sobre as omissões estatais em seus diferentes níveis e, principalmente, as críticas mais expressivas diante da violência no campo contra os trabalhadores.

Nossa análise delimitou-se no estudo dos deputados federais que foram eleitos na década de 1990, respectivamente nos pleitos eleitorais de 1990 1994 e 1998, e aqui entendidos como os "políticos profissionais", com a forma de dedicação a política baseada em quem vive "para" a política que se 'transforma, no sentido mais profundo do termo, em 'fim de sua vida', seja porque encontra forma de gozo na simples posse do poder, seja porque o exercício dessa atividade lhe permite achar equilíbrio interno e exprimir valor pessoal, colocando-se a serviço de uma 'causa' que dá significação à sua vida" (WEBER, 2005, p. 64-65)

$\mathrm{Na}$ perspectiva da carreira política, a atividade parlamentar está relacionada a valores e ideias, na qual surgiram os sentimentos coletivos de reconhecimento duradouro e incondicional. A prática cotidiana de enfrentamento da descrença na política, do ceticismo dos eleitores, da violência dos adversários, das dificuldades financeiras, da falta de tempo nas campanhas, do risco de perder e da infelicidade da derrota mostrariam os percalços da função parlamentar. Para Karina Kuschnir (2000), as características da carreira política são: o treinamento, a entrada na política por meio de alianças e de potenciais eleitores, a fidelidade partidária, a baixa estabilidade e a experiência, com exercício profissional valorizado para a formação de uma identidade parlamentar, sendo que "o estudo dos processos de mudança, ascensão, mobilidade e estabilidade são fundamentais para a compreensão das características de uma carreira" (KUSCHNIR, 2000, p. 58).

O nosso critério para análise dos parlamentares petistas foi a participação na Câmara dos Deputados entre os anos de 1990 e 1998 que tiveram a temática da reforma agrária como discurso cotidiano no plenário da Câmara dos Deputados. A partir daqui, apresentaremos o contexto do Brasil na década de 1990.

As perspectivas políticas para reforma agrária na década de 1990: o neoliberalismo, o Partido dos Trabalhadores e o Movimento dos Trabalhadores Rurais Sem Terra (MST) 
No Brasil, a década de 1990 foi o momento político em que ocorreu a efetivação da proposta neoliberal. A expansão do neoliberalismo na América Latina, principalmente no Chile, no Uruguai e na Argentina na década de 1970, ocorreu com enfoque monetarista e atingiu a organização da economia e da sociedade, "o projeto neoliberal visava instalar uma nova disciplina no corpo social, imprimindo ênfase nas políticas econômicas como remédio para as economias altamente inflacionárias e com elevados déficits na balança de pagamentos que esses regimes tinham herdado do período anterior" (GROS, 2003, p. 33). No caso chileno, a participação dos empresários nacionais foi fundamental para a prática de políticas estabilizadoras, consolidadas com as reformas econômicas e institucionais. As propostas para a área econômica foram: "privatizações e abandono das funções reguladoras e desenvolvimentistas do Estado; liberalização do mercado no que se refere a preços e mercado de capitais; e abertura da economia para o capital internacional" (GROS, 2003, p. 38-39). As mudanças institucionais propostas aconteceram pela: "reforma trabalhista, do sistema de previdência social, privatização da prestação de serviços sociais, descentralização administrativa e, sobretudo, a reforma política" (GROS, 2003, p. 39).

As reformas chilenas eram exemplos de modernidade e de modernização neoliberal para os países que assimilaram as mudanças radicais e as políticas neoliberais: política trabalhista, previdência social, educação, saúde, descentralização regional, agricultura e aparato judicial. As reformas tiveram a eficácia de minimizar a importância da política e da ação coletiva organizada para a sociedade, a despolitização dos problemas sociais, a imposição da perspectiva individualista e da estabilidade capitalista.

No Brasil, a década de 1980 foi marcada pela força e atuação dos trabalhadores na política, por meio dos sindicatos, dos movimentos sociais e populares e dos partidos políticos. Os trabalhadores tiveram presença e influência na Constituição Federal, principalmente pela necessidade de políticas distributivas e de combate na concentração de renda e alteração no modelo econômico vigente no período do regime militar. As elites brasileiras tentaram implantar o neoliberalismo como projeto político hegemônico na década de 1980 para enfrentar e vencer a resistência dos trabalhadores, e marcar a presença e a atuação na política brasileira, por meio dos Institutos Liberais.

Estes tiveram a função de divulgar os princípios do liberalismo baseados na supremacia do indivíduo sobre o Estado, na atividade econômica, e na valorização do mercado para combater o planejamento e a regulação estatal. A ação política dos institutos liberais aconteceu com a tradução e a publicação de livros e de revistas, a divulgação de seminários, colóquios, conferências, cursos e palestras, a presença em jornais e rádios e principalmente com as propostas de políticas públicas (GROS, 2003, p. 14). Concomitantemente a proposta neoliberal, o Partido dos Trabalhadores, mostrou a necessidade da reforma agrária nas suas resoluções de encontros e congressos e por meio dos discursos dos seus deputados federais na Câmara dos Deputados.

A proposta de reforma agrária foi defendida pelo Partido dos Trabalhadores desde o início da década de 1980. No $1^{\circ}$ Encontro Nacional, realizado na Assembléia Legislativa do Estado de São Paulo, nos dias 8 e 9 de agosto de 1981, o PT definiu o problema da distribuição das terras no país como o causador dos ciclos migratórios, do inchaço das cidades, do aumento dos preços e da importação de alimentos. O Partido dos Trabalhadores mostrouse indignado com a falta de solução política para o problema da terra no país e defendeu o sindicalismo rural e a união entre as reivindicações do campo e da cidade do Brasil, porque "o homem da terra está fazendo uma reforma agrária por suas próprias mãos. Como partido, é dessa luta que queremos colher os elementos concretos, práticos, que nos permitirão definir uma política precisa sobre a questão da terra" (RESOLUÇÕES DE ENCONTROS E CONGRESSOS, 1998, p. 109).

No $3^{\circ}$ Encontro Nacional, realizado no Pampas Palace Hotel, em São Bernardo do Campos, entre os dias 6 e 8 de abril de 1984, o PT defendeu a principal reivindicação dos trabalhadores do campo: a posse e o uso da terra. Para o partido, as transformações nas relações de trabalho e de propriedade no campo não poderiam se limitar ao alcance econômico, porque a reforma agrária tem a perspectiva da mobilização, da conscientização e da organização dos trabalhadores. A realização da reforma agrária deveria ser complementada com "o fornecimento de créditos, tecnologia, transporte, silagem, levando-se em conta as diferentes categorias de trabalhadores rurais brasileiros, como pequenos proprietários, parceiros, posseiros e empregados" (RESOLUÇÕES DE ENCONTROS E CONGRESSOS, 1998, p. 150-151).

Nos dois encontros percebe-se que a necessidade de união entre as reivindicações do campo e da cidade brasileira e a exigência das ações governamentais para a instalação, a produção e o desenvolvimento da 
reforma agrária e do trabalhador rural brasileiro foram as principais bandeiras defendidas pelo Partido dos Trabalhadores.

No $7^{\circ}$ Encontro Nacional, realizado entre os dias 30 de maio e 3 de junho de 1990, no Palácio das Convenções do Anhembi, na cidade de São Paulo, o Partido dos Trabalhadores reafirmou a continuidade da reforma agrária como bandeira de luta democrática, popular e anticapitalista, que se concretizaria com a socialização das empresas agroindustriais e o desenvolvimento de cooperativas de pequenos produtores. Para o PT, a reforma agrária defendida pela burguesia se limitaria aos interesses particulares e não atenderia os interesses dos trabalhadores rurais, por isso haveria a necessidade da existência de pequenas propriedades rurais, de empresas e de cooperativas socializadas, e de empresas agrícolas particulares para a construção do socialismo. "O fundamental é que o eixo do processo de socialização ocorra com a participação efetiva e democrática dos trabalhadores, com sua adesão voluntária às medidas de socialização e que estas obedeçam tanto a razões econômicas quanto sociais e políticas" (RESOLUÇÕES DE ENCONTROS E CONGRESSOS, 1998, p. 474).

No $8^{\circ}$ Encontro Nacional, realizado entre os dias 11 e 13 de junho de 1993 , no Centro de Convenções, em Brasília, o PT defendeu a democratização da terra como estratégia do projeto nacional partidário, que romperia com o latifúndio e combinaria a ação governamental e a mobilização das forças populares. O Partido dos Trabalhadores definiu a proposta da reforma agrária para estimular o desenvolvimento econômico do país e avançar na luta pelo socialismo por meio do "apoio à luta dos camponeses pela terra, através das ocupações, com a ação do nosso governo para viabilizar os assentamentos e possibilitar a formação de novas empresas rurais, geridas pelos próprios trabalhadores" (RESOLUÇÕES DE ENCONTROS E CONGRESSOS, 1998, p. 555).

No $9^{\circ}$ Encontro Nacional, realizado entre os dias 29 de abril e $1^{\circ}$ de maio de 1994, no Congresso Nacional em Brasília, o PT definiu como prioridade as bandeiras da reforma agrária, da distribuição de renda, da retomada do crescimento econômico, da erradicação da miséria, da revolução educacional e da recuperação dos serviços públicos para os brasileiros que levariam a vitória de Lula na eleição presidencial em 1994. Para o Partido dos Trabalhadores, o conteúdo do programa do futuro governo democrático e popular se resumiria em idéias-força como: emprego, salário decente, comida, terra, casa, escola, saúde, cadeia para os corruptos e fim da violência. A construção de projetos, de prazos, de metas e de números palpáveis seria considerada na "difusa vontade de mudança que hoje se aglutina em torno de Lula precisa ser politizada e transformada em compromisso concreto de luta pelas reformas" (RESOLUÇÕES DE ENCONTROS E CONGRESSOS, 1998, p. 586-587).

No $10^{\circ}$ Encontro Nacional, realizado entre os dias 18 e 20 de agosto de 1995, no Serviço Social do Comércio (SESC) / Guarapari, no Espírito Santo, a definição da proposta partidária foi: pela defesa da reforma agrária, pelo fim da violência e pela punição dos responsáveis pelos crimes nos campos. As ações do MST e dos trabalhadores do campo seriam importantes na luta pela reforma agrária, e o PT deveria traduzir a sua proposta de reforma agrária "em ações partidárias concretas e permanentes" (RESOLUÇÕES DE ENCONTROS E CONGRESSOS, 1998, p. 555).

Nos anos de 1990, as alianças políticas e partidárias mostraram a necessidade do processo de socialização e de adesão voluntária à reforma agrária no país, por meio da ação governamental, da mobilização das forças populares, e da autonomia partidária para propor as reformas para o país.

As propostas do PT para a reforma agrária perpassaram os anos entre 1980 e 1990, com mudanças na forma de realização política. Na década de 1980 foram definidas as necessidades de união entre as reivindicações do campo e da cidade brasileira e a exigência das ações governamentais para a instalação, a produção e o desenvolvimento da reforma agrária e do trabalhador rural brasileiro. Nos anos de 1990, as propostas partidárias defendidas foram: as alianças políticas e partidárias mostraram a necessidade do processo de socialização e de adesão voluntária à reforma agrária no país, por meio da ação governamental, da mobilização das forças populares, e da autonomia partidária para propor as reformas para o país.

A partir da análise das fontes partidárias percebe-se uma mudança no modo como o partido definiu sua atuação diante da reforma agrária. Nos anos 1980 havia mais a autonomia e a exigência partidária para a efetivação da questão da terra no país, o que na década de 1990 mudaria para a prática política da negociação, das alianças e da soluções políticas e sociais por meio da luta institucional. A crença na reforma agrária por meio da socialização das terras e da adesão voluntária de partidos e dos movimentos sociais demonstrou a tentativa do PT em ser o condutor da reforma agrária no país, por meio das reivindicações dos trabalhadores do campo e do apoio de todos os aliados políticos, sem críticas e sem questionamentos.

O Partido dos Trabalhadores reagiu às propostas de reformas neoliberais, priorizando o social como área de ação política. Por isso, as temáticas sociais 
generalizantes e universais como escola, saúde e crescimento econômico demonstraram a mudança na atuação no Congresso Nacional pelos parlamentares petistas. Na década de 1990, a luta parlamentar teve como prioridade a exigência da regulamentação e do cumprimento da Constituição Federal de 1988 por parte dos Governos Federais em três temas: a reforma agrária, o salário mínimo e a previdência social. As temáticas defendidas pelo PT para o cumprimento constitucional serão atacados incessantemente pelas propostas neoliberais entre os anos de 1990 e 1998.

O PT tentou abranger suas bases sociais incluindo os trabalhadores rurais sem terra, os pequenos e os médios proprietários, os trabalhadores de empresas privadas e os servidores públicos, os aposentados e os pensionistas e os partidos democráticos e populares na década de 1990 por meio da luta parlamentar. A definição do PT pelo apoio institucional dos partidos democráticos e populares representou a definição de critérios para as alianças no combate ao neoliberalismo, na defesa das reformas sociais e no cumprimento das leis definidas da Constituição Federal.

A análise da reforma agrária deve considerar a atuação do Movimento dos Trabalhadores Rurais Sem Terra como ator político pertencente ao processo histórico de resistência do campesinato. Para Bernardo Mançano Fernandes (2000), o MST lutaria contra os projetos políticos e econômicos direcionados pelos governantes brasileiros para a agricultura e a concentração da propriedade de terras. As reivindicações pela reforma agrária teriam nas ocupações e nos acampamentos, a prática política do movimento diante dos órgãos públicos. A conquista das terras e a contrariedade à proposta governista de colonização marcariam os primeiros anos do MST, constituído no final da década de 1970, e representariam a ação contínua de espacialização da luta pela terra por meio da participação, da direção coletiva, da descentralização administrativa e do trabalho de base.

A ocupação de terras seria a identidade política do MST para reivindicar desapropriações de fazendas para assentar as famílias dos trabalhadores rurais sem terra, para resistir aos métodos repressivos e desmoralizadores dos governantes brasileiros, para produzir alimentos para a subsistência das famílias assentadas, porque "a solução para os conflitos só viria com a desapropriação" (FERNANDES, 2000, p. 124). O MST teria como finalidade a continuidade de organização e de desenvolvimento dos trabalhadores rurais sem terra por meio da formação política, da educação, da administração e da comunicação, que se constituiriam na estrutura organizativa e nas instâncias de representação política do movimento.
Os governos neoliberais na década de 1990 reagiriam com repressão, violência, impunidade e perseguição política à expansão e a territorialização da reforma agrária defendida pelo MST que "intensificou a luta pela terra, de modo que na década de 1990 cresceram tanto o número de ocupações quanto o número de assentamentos, em todas as regiões" (FERNANDES, 2000, p. 200). Os assentamentos conquistados nos anos 1990 representariam as intensificações das ocupações contra as políticas neoliberais no país, que continuariam com o aumento do desemprego, a concentração de terras e a expropriação e a exploração da produção rural.

A ocupação como método de ação política envolveria terras de recuperação, devolutas e de latifúndios improdutivos, os acampamentos como espaços interativos e comunicativos das lutas e as marchas como expansão das negociações e de fatos novos colocariam a luta pela terra como luta contra o capital que criminalizaria as reivindicações pela reforma agrária no país. Para Fernandes, "criminalizar as ocupações é se esquivar do problema sociopolítico e econômico que elas representam" (FERNANDES, 2000, p. 281).

A autonomia e a independência dos trabalhadores rurais sem terra na luta pela reforma agrária mostraram os limites das propostas governistas para o problema da propriedade no país. A colonização, a negação do acesso à terra, a violência nos campos e a criminalização dos movimentos rurais eram os critérios políticos utilizados pelas diferentes esferas de governo no Brasil diante da reforma agrária no país, que era questionada como um interesse corporativo, e não um interesse coletivo. O elemento político da terra mostrou a crença do MST na reforma agrária, em que os governantes definiram as políticas agrárias e agrícolas, ignoraram o desemprego, a exploração e a expropriação dos trabalhadores e das produções rurais, continuaram com a desigualdade do acesso a terra e não aceitaram críticas e nem questionamentos.

O contexto político dos anos 1990 mostrou três perspectivas diferentes para a solução da questão da terra: os governos federais que ignoraram a questão da reforma agrária em prol da proposta neoliberal; o Partido dos Trabalhadores que tentou ser o condutor da questão da terra por meio das propostas como socialização das terras e da adesão voluntária de partidos e dos movimentos sociais, das temáticas sociais generalizantes e universais como escola, saúde e crescimento econômico, e da tentativa de abranger suas bases sociais incluindo os trabalhadores rurais sem terra, os pequenos e os médios proprietários, os trabalhadores de empresas privadas e os servidores públicos, os aposentados e os pensionistas e os partidos democráticos e 
populares por meio da luta parlamentar; e do MST que conseguiu por meio das ocupações e dos assentamentos efetivar o sonho da reforma agrária.

Os três atores mostraram perspectivas diferentes para a ação política diante da temática da terra, veremos com mais profundidade como os deputados federais do PT lutaram pela reforma agrária na Câmara dos Deputados: se entre o indivíduo (parlamentar) atuou com autonomia ou se se restringiu as orientações do ator coletivo (partido político). Assim, tentaremos perceber se houveram múltiplas identidades demonstrando fontes de tensão e contradição na defesa dos interesses políticos e na ação em prol da problemática da terra.

\section{Os discursos dos deputados federais do Partido dos} Trabalhadores

A seguir faremos uma análise dos discursos dos deputados federais do Partido dos Trabalhadores na década de 1990 sobre a temática da reforma agrária. Dentro das possibilidades de luta parlamentar, os atores políticos mobilizaram três critérios para agir, criticar e revelar a importância da causa no país. Por meio das omissões governamentais, das propostas partidárias e individualizadas e das violências sofridas pelos movimentos do campo, os parlamentares do PT construíram uma concepção sobre a situação agrária do país e demarcaram uma forma de atuação política na Câmara dos Deputados.

\section{As omissões governamentais}

As omissões mais contundentes foram apresentadas por Adão Pretto e Paulo Rocha. Para os parlamentares petistas, a reforma agrária ampla e massiva, sob o controle dos trabalhadores, seria a solução para os problemas do Brasil, como a importação de alimentos, o êxodo rural, o inchaço das cidades e o desemprego. O parlamentar Adão Pretto argumentou que a União Democrática Ruralista (UDR) lançou nota em jornal afirmando a sua disponibilidade para entrar em guerra, e "vai pegar em armas para tirar à força os agricultores que fizerem qualquer investida nas propriedades". ${ }^{4}$ Para o deputado federal, o êxodo rural tem relação direta com a reforma agrária porque contribui "para aumentar o desemprego e a miséria, causa principal da violência na cidade e no campo". ${ }^{5}$ A permanência dos casos de violência

e a convicção da necessidade da reforma agrária, por meio de projetos de ${ }^{4}$ Diário do Congresso Nacional. Seção I, Ano XLVI, no . 149, 31/10/1991, p. 21563.

${ }^{5}$ Diário do Congresso Nacional. Seção I, Ano XLVI, n'. 149, 31/10/1991, p. 21564. leis são pontos importantes para a defesa incondicional da reforma agrária no país. Adão Pretto afirmaria que, no projeto de lei apresentado na Câmara dos Deputados no ano de 1993, os proprietários de terras produtivas não sofreriam as consequências, afinal "se aprovarmos este projeto, e houver desapropriação de terras na metade dos latifúndios improdutivos do Brasil, poderemos assentar todos os colonos sem terra do País" . ${ }^{6}$

Para Ariovaldo Umbelino de Oliveira, a relação entre a cidade e o campo deve ser entendida na unidade dialética como um processo avançado de cooperação no trabalho e nas diferenças que se aprofundam com características gerais de ambas, "o que significa dizer que a compreensão dos processos que atuam na construção/expansão das cidades passa pela igualmente necessária compreensão dos processos que atuam no campo". (OLIVEIRA, 2013, p. 65). Para o autor, o traço essencial da estrutura fundiária: o caráter concentrado de terras, principalmente por meio da expropriação ou anexação das pequenas propriedades em áreas acima de 100 hectares, e nas propriedades abaixo de 100 hectares permanece o trabalho familiar.

É, pois, no bojo dessa articulação entre o processo de expansão desigual do trabalho assalariado no campo, na expansão do também desigual processo de expropriação e no dominante processo histórico da concentração fundiária do país que vamos encontrar contraditoriamente a origem dos conflitos e da luta pela terra no Brasil com sua marca histórica: a violência. (OLIVEIRA, 2013, p. 80)

A perspectiva de reforma agrária por meio da desapropriação de terras para atingir os colonos é similar a questão levantada do trabalho familiar em áreas de menos de 100 hectares. E no centro do processo, a violência apareceu como uma ligação intrínseca, pois atingiu os trabalhadores e foi utilizada como retaliação a proposta de divisão das terras. Desapropriação de terras, trabalho familiar e violência formaram uma tríade difícil de ser solucionada na questão agrária e nos discursos dos deputados federais petistas e nas propostas governamentais.

${ }^{6}$ Diário do Congresso Nacional. Seção I, Ano XLVIII, nº. 12, 28/1/1993, p. 1938. O conflito como motivação principal das disputas em torno da propriedade e do uso da terra e a desigualdade social, a assimetria de poder e a impunidade dos agentes como parte fundamental da violência no Brasil são analisador por (BRUMER \& SANTOS, 2006). Assim, o uso improdutivo das terras não é um argumento homogêneo entre o discurso político e a análise acadêmica. 
Os governos neoliberais dificultaram a realização da reforma agrária por meio da exigência do pagamento de dívidas dos trabalhadores do campo, da limitação dos créditos rurais, dos assentamentos de famílias acampadas, da falta de assistência técnica e do direcionamento dos recursos para os latifundiários. Para Adão Pretto, existe a possibilidade de direcionar o dinheiro para as seguintes áreas: a produção de alimentos, a reforma agrária, o perdão da dívida de pequenos agricultores, o custeio da lavoura de pequenos agricultores e a construção da casa própria. Assim, o "Governo não pode estar preocupado só com meia dúzia de multinacionais, grandes empresários, usineiros e banqueiros, mas com o povo brasileiro, porque podemos tirar o Brasil da situação em que ele se encontra".?

O Governo Federal, entre os anos de 1990 e 1994, mostrou sua imobilidade nas decisões sobre o setor agrícola brasileiro. Para Adão Pretto, os ministros e os secretários no Ministério da Agricultura eram incompetentes porque apenas falaram números e não colocaram em prática a aplicação de valores que, efetivamente, aumentaram a produção de alimentos no país. O deputado federal levantou as seguintes questões: "os homens que ocupam altos postos no Governo enxergam as coisas, mas não tomam decisões. Por que não o fazem? O Brasil está precisando de quê? O que está entravando o desenvolvimento do país?" ${ }^{8}$ A sua conclusão era a falta de coerência, de dignidade, de caráter e de vontade política - algo absolutamente incompreensível.

De cada três hectares disponíveis só um está sendo ocupado, e ocupado mal. No Brasil, 12 milhões de agricultores não têm terra; há mais ou menos 8 milhões ou mais de desempregados nas cidades; 32 milhões de brasileiros passam fome, e mais de 70 milhões se alimentam mal, por falta de recursos. ${ }^{9}$

Para João Pedro Stédile, a negação do problema agrário no país feita pela burguesia e pelo governo mostra que a propriedade de terra não é empecilho para o desenvolvimento do capitalismo no Brasil, principalmente porque optou pela grande propriedade: "o fato de existirem grandes propriedades facilitou que se implantasse de maneira mais rápida o crédito rural, que se implantasse uma modernização mais rápida, a mecanização e a monocultura" (STÉDILE, 2013, p. 373). Para o autor, o capitalismo presente na agricultura

por meio da acumulação, da concentração e da centralização concentra a terra e permanece a imigração campo e cidade. Neste ponto, a reforma agrária deve resolver o problema agrário, principalmente porque a burguesia considera problemas com sem-terra como problemas políticos, e "são vistos como problema agrário, que tenha que mudar a estrutura da propriedade agrária" (STÉDILE, 2013, p. 379).

A omissão governista ao analisar números e não colocar em prática uma política favorável a reforma agrária coincide com a condução da burguesia aos problemas agrários. Na prática, a atitude governista e burguesa mantém a concentração de terras intocável, a prioridade para as grandes propriedades e a negação da reforma agrária com a sua função social.

A política praticada pelo Governo Federal neste período baseada nos juros altos, no privilégio e na isenção de impostos para os latifundiários, na cobrança de dívidas agrícolas para os pequenos agricultores, e na retenção de recursos para a reforma agrária demonstrou o limite governamental na atuação diante da agricultura. Para Paulo Rocha, há uma descrença em acreditar no diálogo com o Executivo porque a Assessoria de Orçamento da Câmara dos Deputados realizou um estudo que comprova a retenção de recursos previstos para a área social e a reforma agrária no ano de 1995 e constatou "que apenas $3,47 \%$ do total previsto para a reforma agrária foi liberado. Isto é um exemplo claro da falta de vontade política para resolver o problema da concentração da terra". ${ }^{10}$

Para o deputado federal, os dados utilizados acima também ressaltaram que no Orçamento do ano de 1995 não foi repassado cerca de R\$ 36,2 milhões para a reforma agrária e isto mobilizava o MST a agir sem negociar com o Governo Federal, já que não há nenhuma atitude favorável à questão da terra no país. Esta postura agravou os problemas, os conflitos e o descaso com os assentados que precisavam “de infra-estrutura básica como estradas, postos de saúde, escolas, eletrificação rural, assistência técnica, crédito agrícola e transporte para escoamento da produção". ${ }^{11}$

O discurso defendido pelo parlamentar na tribuna da Câmara dos Deputados foi criticado pelos deputados federais governistas como puramente retórico e com dados vazios, contudo o desprezo do Governo Federal com as questões sociais, principalmente a terra, estava refletido em dados reais.

${ }^{10}$ Diário da Câmara dos Deputados. Ano LI, no ${ }^{\circ} .87,17 / 5 / 1996$, p. 14094. ${ }^{1}$ Diário da Câmara dos Deputados. Ano LI, no ${ }^{\circ} .87,17 / 5 / 1996$, p. 14094 
Nas negociações com a Oposição e com o movimento social, o Governo diz muita coisa e até promete. Mas na sua ação política e, principalmente, na sua base parlamentar, aqui, no Congresso Nacional, tanto na Câmara como no Senado, vai totalmente de encontro ao discurso falacioso, carregado de mídia, para a população. O concreto é que não há uma boa vontade política por parte do Governo Fernando Henrique Cardoso no que se refere à reforma agrária e aos problemas do campo, como, por exemplo, a violência. ${ }^{12}$

Para José Eli da Veiga, a reforma agrária tem um sentido distributivo realizado com a intervenção do Estado. O autor utiliza como exemplos de reforma agrária: a japonesa, a taiwanesa, a coreana, a egípcia e a mexicana para examinar como o papel da agricultura desempenha no processo geral de desenvolvimento e no impacto redistributivo entre a população urbana. Para Veiga, o objetivo da intervenção era garantir comida farta e barata para a crescente população urbana por meio do desenvolvimento da agricultura familiar e "a intervenção estatal visa remunerar o trabalho do agricultor, e não garantir a rentabilidade de seus investimentos em níveis comparáveis à rentabilidade dos investimentos industriais, comerciais, bancários etc" (VEIGA, 2013, p. 98).

A opção governista por restringir o orçamento da reforma agrária reforça o argumento de omissão e de não prioridade para a questão da terra no Brasil e o discurso político se aproxima da análise acadêmica ao demonstrar que a reforma agrária deve atingir pontos importantes além da posse da terra, como a opção pela agricultura familiar e o desenvolvimento da infraestrutura para a melhoria das condições de vida dos assentados.

O Governo Federal, entre os anos de 1995 e 1998, tentou transferir sua responsabilidade sobre a reforma agrária para os governos municipais, limitou o acesso ao Programa Nacional deAgricultura Familiar(PRONAF), e transformou o INCRA em imobiliária fundiária com a criação do programa Cédula da Terra.

O deputado federal Adão Pretto afirma que o Ministro Extraordinário de Política Fundiária Raul Jungmann, defendeu no Seminário Nacional sobre Reforma Agrária realizado com os Prefeitos eleitos no ano de 1996 de todo o país, que ocorreria - a transferência de cadastro, de levantamento de terras e da constituição dos conselhos de reforma agrária - ou seja, de responsabilidades do Governo Federal para os Governos Municipais. A efetivação da proposta do Governo Federal tem a intenção de isolar e impedir

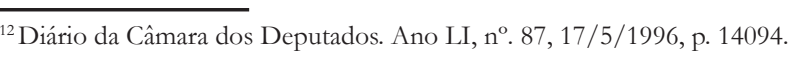

os trabalhadores rurais sem terra de participarem das políticas de reforma agrária, "pois é notório, em nosso País o poder que os grandes latifundiários exercem sobre os poderes municipais, o que inviabilizaria politicamente qualquer ação mais ousada". ${ }^{13}$

Para o parlamentar, o Executivo também estava publicando dados inverídicos sobre o assentamento de famílias, "os dados do Incra do mês de setembro apontavam o assentamento de 24 mil famílias. Na semana passada, em audiência pública, o Ministro afirmou ter assentado até agora $50 \mathrm{mil}$ famílias". ${ }^{14} \mathrm{O}$ critério utilizado pelo Governo Federal era direcionado para todos os decretos publicados, e o critério utilizado pelo deputado federal do PT era somente após a contestação dos proprietários de terra na Justiça, o que levava no mínimo dois anos para imissão de posse na área.

O envio de medidas provisórias referentes a reforma agrária era outra prática do Executivo para desmoralizar a atuação do Congresso Nacional diante da temática da terra. No projeto enviado no ano de 1997 constava a simulação de ocupações pelos fazendeiros das próprias terras, sob o argumento de que terras invadidas não podem ser desapropriadas. Para Adão Pretto, o uso desta medida provisória impedia o desencadeamento da reforma agrária no país e seria "mais uma aberração deste Governo, que realmente trata das questões sociais do Brasil com tamanho desprezo". ${ }^{15}$

Novamente, os dados relacionados a liberação de recursos foram omitidos pelo Executivo com o objetivo de dissimular os investimentos feitos na agricultura. Os números governistas falavam em 8,5 bilhões para a agricultura e apenas 1,5 bilhão para a agricultura familiar, representada pelo Programa Nacional de Agricultura Familiar (PRONAF) e 1 bilhão para a pequena propriedade, quando somente 500 mil foram liberados. Para Adão Pretto, o PRONAF é uma demagogia porque poucos agricultores têm acesso ao programa: de um total de 430 mil famílias, apenas 3 mil foram contempladas até o ano de 1997.

O Rio Grande do Sul possui 427 Municípios, e somente 113 forma contemplados pelo Pronaf. Muitos desses Municípios contemplados têm em média três ou quatro agricultores contemplados. Há Município que está entre os 113 contemplados, e nenhum agricultor ainda conseguiu o Pronaf. ${ }^{16}$

\footnotetext{
${ }^{3}$ Diário da Câmara dos Deputados. Ano LI, no. 199, 12/12/1996, p. 32886. ${ }^{14}$ Diário da Câmara dos Deputados. Ano LI, no. 199, 12/12/1996, p. 32887. 15 Diário da Câmara dos Deputados. Ano LII, nº. 98, 18/6/1997, p. 16500. ${ }^{15}$ Diário da Câmara dos Deputados. Ano LII, ño 98, 18/6/1997, p. 16500.
${ }^{16}$ Diário da Câmara dos Deputados. Ano LII, no ${ }^{\circ} .98,18 / 6 / 1997$, p. 16501.
} 
Para Ricardo Abramovay, a agricultura familiar tem um peso decisivo no processo de modernização nos países centrais como Estados Unidos, GrãBretanha e na Europa Continental. Nestes lugares, os preços dos produtos agrícolas são decididos em esferas públicas e universais, fazendo com que os mercados sejam organizados institucionalmente e o Estado intervém na questão da agricultura para determinar a renda, nas políticas de estrutura, nas políticas sociais por meio de políticas fundiárias produtivistas, e não distributivistas como na América Latina, e na posse e no uso da terra, que são direcionados para o progresso técnico. Para o autor, a importância da agricultura não pode se reter nas máquinas e nos insumos, e sim considerar a produção familiar "no sentido de que o patamar mínimo para o funcionamento da atividade vai aumentando em todos os países capitalistas" (ABRAMOVAY, 2013, p. 120).

\section{As propostas dos parlamentares para a efetivação} reforma agrária

As principais propostas apresentadas em plenário da Câmara dos Deputados foram feitas por Fernando Ferro, Adão Pretto e Paulo Rocha.

Fernando Ferro analisou a situação da fazenda Safra no submédio do São Francisco em Pernambuco por meio do discurso do Ministro da Agricultura e do presidente do Incra que afirmaram a necessidade de intervenção militar nos conflitos rurais no país, isso mostra que o Governo pode desenvolvendo ações "justamente para buscar situações negociadas, mediadas no campo, para evitar essa tragédia a que assistimos diariamente, se ponha a serviço da disseminação da violência". ${ }^{17}$

O deputado federal demonstrou a sua disponibilidade para negociar alternativas com os trabalhadores sem terra, a Igreja, os Parlamentares e os donos da terra, sobre o deslocamento de 2200 famílias para uma fazenda vizinha ou a prorrogação do prazo junto ao Banco do Brasil. A negociação era importante para ressaltar que o grito da terra não pode ser tratado como uma questão policial porque as lutas sociais devem ser objeto de intervenção política. "Portanto, peço ao Governo Federal que tome a iniciativa de nos ajudar nessa negociação. Tenho conhecimento de que o Governo pode interferir nesse processo de despejo, evitando-se um conflito com os trabalhadores rurais". ${ }^{18}$

Para Vera Lúcia Vieira, as lutas sociais ocorridas após a publicação da

${ }^{17}$ Diário do Congresso Nacional. Seção I, Ano L, no .149, 23/9/1995, p. 23344.

${ }^{18}$ Diário do Congresso Nacional. Seção I, Ano L, nº. 149, 23/9/1995, p. 23345.
Constituição Federal de 1988 sofrem a violência institucionalizada por serem consideradas ameaçadoras de um ordenamento social, "mesmo nos casos em que suas demandas sejam apenas por reformas necessárias à viabilização do próprio capitalismo" (VIERIA, 2005, p. 197).

A disponibilidade para negociar por parte dos parlamentares petistas e o uso da violência por parte do governo federal também mostram como a questão agrária no país foi usada por parte dos poderes políticos. Ao criminalizar os movimentos sociais, o governo afirma que não há solução possível para o problema da terra e qualquer reivindicação não atinge o cerne da questão: a situação terra não será modificada, mesmo que para isso a própria sociedade tenha que morrer. Ao propor a negociação como método de solução, os deputados federais possibilitam pensar juntos em possibilidade que atinja a todos envolvidos na questão da propriedade de terras no país.

O Governo Federal tentou a implantação da reforma agrária por meio do projeto Cédula da Terra, que teria a parceria do Banco Mundial e já teria sido implantado na África, na Ásia e na América Latina. Para Adão Pretto, o Cédula da Terra tem a intenção de baratear a compra da terra, transformar o Incra numa imobiliária fundiária, e acabar "com o binômio desapropriaçãoassentamento, instrumento clássico de reforma agrária no mundo inteiro". ${ }^{19}$

O deputado federal argumenta que a pior terra seria vendida pelo melhor preço, os colonos seriam aprisionados em dívidas com os bancos, sem condições de cultivar alimentos em associação e levaria ao engano sobre a efetivação da reforma agrária, pois "a reforma agrária só vai melhorar quando houver vontade política de enfrentar o latifúndio, realizando uma reformulação fundiária, escolhendo áreas para plantar e dotando-as das condições que emancipem o assentado". ${ }^{20}$

Para o deputado federal, duas condições eram necessárias para a efetivação da reforma agrária no país: o crédito do Programa Especial de Crédito para a Reforma Agrária (Procera) justo e condizente com os desafios dos assentados para a assistência técnica, escola, atendimento a saúde; e a ação com urgência na desapropriação de terras improdutivas, que agridem o meio ambiente, que têm trabalho escravo e que plantam substâncias psicotrópicas porque o mecanismo de compra de terras já foi realizado sem sucesso no passado.

${ }^{19}$ Diário da Câmara dos Deputados. Ano LII, ño. 142, 15/8/1997, p. 23671. Para Sérgio Sauer, o Cédula da Terra é um projeto piloto, "como uma experiência alternativa de acesso à terra via mecanismo de compra e venda" (SAUER, 2010, p. 100).

${ }^{20}$ Diário da Câmara dos Deputados. Ano LII, no ${ }^{\circ}$ 142, 15/8/1997, p. 23671. 
Ele traz em si o perigo de estarmos dando regularidade aos processos de grilagem de terras, impedindo a luta para tomar a terra de quem a roubou. Queremos impedir a ciranda de compra e venda de pequenos proprietários, que serão os principais participantes desse equivocado programa. ${ }^{21}$

Para Sérgio Sauer, o Governo Federal neste período buscou aliança com o Banco Mundial em programas de acesso a terra para diminuir os conflitos e combater a pobreza rural e os recursos vindos do Banco Mundial "permitiram ao governo FHC amenizar a pressão social por terra sem alterar a estrutura fundiária ou ampliar os processos de desapropriação" (SAUER, 2010, p. 100). A proposta do Banco Mundial concebe a reforma agrária como medida social, mas tira a responsabilidade do Estado - que critica o método da desapropriação, por meio de uma crítica abstrata, homogeneizadora e universalista, além de morosas, caras e ineficientes.

A intenção era de rebaixar politicamente e redefinir o sentido da própria reforma agrária, criando uma disputa de protagonismo político e deslegitimar as ações dos movimentos sociais, especialmente entre 1995-2002, pois “a criação de uma linha de crédito para a compra de terra deslocou parcelas significativas de camponeses das mobilizações e luta, que passaram a sonhar com acesso à terra via compra" (SAUER, 2010, p. 117).

Ao colocar em prática a proposta do Banco Mundial, o Governo Federal percebe a desapropriação como um processo coercitivo e conflitivo, não admite o conflito como parte fundante da democracia e reproduz a ideologia neoliberal com a crítica ao Estado como um entrave para o desenvolvimento. Na prática, a lei da oferta e da procura nega a reforma agrária constitucional, que é fundamentada no comprimento da função social da propriedade e da terra, "portanto, a terra possui um caráter multidimensional (político, econômico, cultural e ambiental)" (SAUER, 2010, p. 119).

O Executivo mudou a forma de ação junto ao MST: do diálogo e das negociações passou para o autoritarismo, ressaltando a questão política e direcionando a sociedade brasileira contra o movimento social. Para Paulo Rocha, os argumentos são antigos e usados por governantes que "quando se sentem acuados pelos movimentos sociais, quando o Estado se sente obrigado a dar respostas às questões prementes do nosso povo, da nossa gente". ${ }^{22}$

\footnotetext{
${ }^{21}$ Diário da Câmara dos Deputados. Ano LII, no. 142, 15/8/1997, p. 23672.

${ }^{22}$ Diário da Câmara dos Deputados. Ano LIII, no ${ }^{\circ}$. 61, 9/4/1998, p. 9584.
}

O deputado federal ressaltou que a política praticada pelo Governo Federal do país se esgotou porque a sua composição e as suas alianças políticas se restringiram aos latifundiários, as agroindústrias e o capital financeiro. "Então, chegou ao limite o número de assentamentos que o Governo Fernando Henrique Cardoso pode conceder para resolver o problema da terra". ${ }^{23}$ Com os olhos direcionados para a reeleição, o Executivo ignorou os problemas do campo, como a necessidade de uma reforma agrária que seja capaz de produzir alimentos, que fixe o homem no campo por meio da média e da pequena propriedade, que se construa um sistema de transporte para escoamento da produção e uma política de preços.

A política do MST está, sim, baseada numa concepção de desenvolvimento, na qual se pensa em desenvolvimento a partir do cidadão, a partir da família, a partir da pequena e média propriedade, uma concepção de desenvolvimento não a partir do grande projeto, dos ricos apenas, mas voltada para os interesses da maioria, dos trabalhadores sem terra dos pequenos agricultores e do pequeno e do médio produtores.

Com financiamento e assistência técnica, com certeza, vamos mudar a situação no campo. Haverá paz, tranqüilidade e desenvolvimento. ${ }^{24}$

Concomitantemente ao uso da violência do Estado diante dos trabalhadores rurais sem terra, as omissões estatais permaneceram por meio da retenção de recursos, da tentativa de transferência da reforma agrária para governos municipais, da limitação do acesso ao PRONAF, da transformação do INCRA em imobiliária fundiária, do envio excessivo de medidas provisórias para o Parlamento nacional e das alianças com os latifundiários, as agroindústrias e o capital financeiro.

\section{As violências contra os movimentos sociais do campo}

No caso das violências, Paulo Rocha, Adão Pretto e Paulo Paim se destacaram na defesa dos trabalhadores e crítica contundente em relação à atuação do Estado. O não reconhecimento dos movimentos que reivindicaram a reforma agrária por parte dos Governos Federais na década de 1990 representou a tentativa de transformá-los em ilegais e ilegítimos, utilizando a força policial para coibir qualquer manifestação a favor da luta

${ }^{23}$ Diário da Câmara dos Deputados. Ano LIII, no. 61, 9/4/1998, p. 9585.

${ }^{24}$ Diário da Câmara dos Deputados. Ano LIII, n' ${ }^{\circ} .61,9 / 4 / 1998$, p. 9585. 
pela terra. ${ }^{25} \mathrm{O}$ caso específico relatado pelo deputado federal Adão Pretto é sobre o massacre de Corumbiara:

Venho a esta tribuna novamente, tratar do desejo ocorrido na Fazenda Santa Elina, no Município de Corumbiara, no Estado de Rondônia As informações sobre o número de mortes ainda são completamente imprecisas. Temos informações de que a polícia isolou e, ontem, durante todo o dia, ninguém conseguiu chegar no local.

A situação é de verdadeira calamidade. Houve um massacre. Os hospitais da região estão lotados de feridos. Infelizmente, mais uma vez a reforma agrária é tratada apenas pela polícia.

Caros colegas, solicitamos ontem a constituição de uma Comissão desta Casa para se dirigir ao local para acompanhar o caso e tentar intermediar uma solução. Também foi formada uma Comissão das entidades, movimentos e Deputados Estaduais daquele Estado.

Sr. Presidente, nobres colegas, é necessário que se responsabilize o proprietário, que haja punição e que a área improdutiva seja desapropriada e entregue aos trabalhadores. Não podemos mais presenciar ações autoritárias que massacram os trabalhadores que somente lutam pela sua sobrevivência. Precisamos responsabilizar o Poder Judiciário pela sua insensibilidade em relação aos problemas da terra e por se aliarem, quase sempre, aos latifundiários. Também precisamos responsabilizar os Governos Estadual e Federal pelo uso que fazem da Polícia Militar e pela sua completa inoperância para fazer a Reforma Agrária.

Esperamos que as comissões que se dirigiram para a área consigam levantar todas as informações detalhadas e que as autoridades tomem as providências cabíveis. ${ }^{26}$

A prática da violência no campo era realizada pelos latifundiários, com a omissão e a participação da polícia militar, do Instituto Nacional de Colonização e Reforma Agrária (INCRA), da Justiça e do Ministro da Agricultura. Para os deputados federais do PT, a difusão da violência nos campos mostrou a existência de problemas agrários em todo o país: Alagoas, Pará, Rio Grande do Sul, Paraíba, Mato Grosso, Mato Grosso do

\footnotetext{
${ }^{25} \mathrm{~A}$ atitude governista é similar a proposta de criminalização dos movimentos sociais de Vera Lúcia Vieira, que "têm como preceito básico, não o atendimento das demandas sociais, mas, pelo contrário, a rearticulação do bloco do poder de forma a apaziguar, cooptar e anular as demandas sociais latentes" (VIEIRA, 2005, p. 198). ${ }^{26}$ Diário do Congresso Nacional. Seção I, Ano L, nº. 120, 11/8/1995, pp. 17549-17550.
}

Sul, Rondônia, São Paulo, Paraná, Distrito Federal, Espírito Santo, Ceará e Pernambuco, estados com assassinatos registrados contra assentados, manifestantes e pequenos agricultores.

O recrudescimento do uso da força militar para solucionar os problemas agrários no país aconteceu em Eldorado dos Carajás, caso limite da violência extrema diante dos manifestantes pela reforma agrária. O envolvimento dos atores políticos e sociais como a polícia militar, o Governador do Estado do Pará - Almir Gabriel -, a Federação da Agricultura do Estado do Pará, o Presidente dos Sindicatos dos Fazendeiros, e o Presidente da República ocorreu por meio da radicalização, da autorização e da omissão das mortes de famílias dos trabalhadores rurais sem terra. O massacre em Eldorado dos Carajás foi assim apresentado no plenário da Câmara dos Deputados no dia 18 de abril de 1996 pelo deputado federal Paulo Rocha:

Nós, os trabalhadores do Pará, estamos de luto. Dezenove agricultores elo MST (Movimento dos Trabalhadores Sem-Terra) foram massacrados e assassinados pela Polícia Militar, em Eldorado de Carajás. Outros 45 trabalhadores estão feridos e hospitalizados. O massacre ocorreu ontem, no final da tarde. Trata-se de mais um capítulo na longa crônica de mortes anunciadas. É que no último dia 2 de abril solicitei aqui da tribuna desta Casa a instalação de uma Comissão Externa, formada por Deputados, para tentar intermediar o conflito envolvendo fazendeiros e sem-terras da região sudeste do Pará.

Já enviei diversas cartas ao Governador do Pará, Almir Gabriel, solicitando o empenho das autoridades federais e estaduais para resolver o conflito. Foi mais forte a pressão dos fazendeiros, os quais desde o último dia 28 de março anunciaram, em Belém, que iriam pegar em armas para retirar os sem-terras da região. O Sr. Geraldo Milton Soares, Vice-Presidente da Federação da Agricultura do Estado do Pará e Presidente dos Sindicatos dos Fazendeiros da região, foi o porta-voz da radicalização dos empresários.

Nós já conhecemos esse procedimento. Trata-se de uma senha para criar um clima, tanto na opinião pública quanto nos aparelhos de repressão. Daí o nosso alerta para o Governador, para os Srs Deputados e para a Mesa Diretora desta Casa, a quem encaminhei pedido de formação da Comissão Externa. Mas não adiantou. Mais uma vez temos que chorar os nossos mortos.

Já são mais de 300 trabalhadores rurais e líderes sindicais assassinados nos últimos 25 anos, segundo levantamento feito pela 
última CPI da Assembléia Legislativa do Estado e atualizada com informações da Comissão Pastoral da Terra.

Enquanto isso, o Presidente Fernando Henrique Cardoso não tem coragem de fazer a reforma agrária. Mas assegura recursos do Tesouro para rolar a dívida dos latifundiários representados pela chamada bancada ruralista no Congresso Nacional.

A responsabilidade por esse massacre e por tudo o que ocorreu aos trabalhadores é do Estado, pela insensibilidade dos que foram alertados para o banho de sangue que poderia ocorrer, mas preferiram ignorar, trabalhadores inocentes e até crianças pagaram com a vida por reivindicarem o cumprimento de um direito que lhes foi negado. Honra e glória aos sem-terras de Curionópolis, que tombaram lutando pelo direito de conquistar um pedaço de terra para produzir. ${ }^{27}$

Para o deputado federal, a responsabilidade pelo massacre em Eldorado dos Carajás era "do Estado, pela insensibilidade dos que foram alertados para o banho de sangue que poderia ocorrer, mas preferiram ignorar, trabalhadores inocentes e até crianças pagaram com a vida por reivindicarem o cumprimento de um direito que lhes foi negado". ${ }^{28}$ Para Adão Pretto, os massacres contínuos mostraram a transformação das polícias militares em braço armado, o INCRA em braço institucional dos latifundiários brasileiros e a Justiça em estimuladora da continuidade das chacinas pela prática da impunidade. Falar-se-ia no episódio havido no Pará até surgir um maior, "depois ninguém mais falará no massacre do Pará. É assim que este País vai-se comportar?", questionaria Adão Pretto. ${ }^{29}$

Para os parlamentares da base governista, os trabalhadores sem terra iniciaram o tumulto com a polícia militar em Eldorado dos Carajás por meio de barricadas, e o Presidente da República seria isentado da responsabilidade de violência. Para Agnaldo Timóteo (PPB), a televisão manipulou as imagens de violência em Eldorado dos Carajás para distorcer a função policial, e os parlamentares da oposição negaram os atos violentos praticados pelos manifestantes.

Estou preocupado. Será que somente eu vi aquelas cenas? Será que os Deputados Paulo Paim, José Genoíno e outros não as viram também? Não é a primeira vez que eles partem contra a polícia, jogando pedras e fazendo pontas em pedaços de pau, para usarem

\footnotetext{
${ }^{27}$ Diário da Câmara dos Deputados. Ano LI, no. 68, 19/4/1996, p. 10225.

${ }^{28}$ Diário da Câmara dos Deputados. Ano LI, ño. 68, 19/4/1996, p. 10225.

${ }^{29}$ Diário da Câmara dos Deputados. Ano LI, no ${ }^{\circ} .68,19 / 4 / 1996$, p. 10263.
}

como arma. Todo mundo viu um facão na mão daquela senhora que levou um tiro na perna, e um revólver na mão de um deles. Nós os vimos atirando! ${ }^{30}$

Para o deputado federal, existe a necessidade de que a verdade fosse mostrada dos dois lados, porque a violência partiu da polícia militar e dos trabalhadores rurais sem terra, por isso, o que aconteceu foi "uma tragédia provocada pela insensibilidade e pelo terrorismo de alguns canalhas que se travestem de líderes dos sem-terra para criar movimentos políticos e tirar proveito da situação política em todas as eleições". ${ }^{31}$

Para Edinho Bez (PMDB), o fato ocorrido era lamentável e, por meio de muitas mentiras, estavam explorando-o politicamente principalmente alguns deputados do Partido dos Trabalhadores, como teria feito José Genoíno, ao dizer que o PT não estimula os movimentos sociais, apenas apoia-os. Para o deputado federal, a população não pode ser enganada com o argumento de que o PT está fora disso, "o PT tem de assumir o papel e estimulador desses movimentos". ${ }^{32}$

Para Paulo Paim, era uma brincadeira, uma irresponsabilidade o discurso parlamentar que relacionava a violência do uso militar da metralhadora e do uso dos manifestantes de pau e de pedras, o que mostrava a falta de seriedade que "este Parlamento, com este nível de debate, desrespeita os mortos e suas famílias. Só sendo débil mental! É não ter o mínimo de sensibilidade, usar esse tipo de argumento num debate sério como o da reforma agrária". ${ }^{33}$

Para José Gomes da Silva, a situação atual da reforma agrária brasileira demonstra como a violência tem três características principais: "seletiva, institucionalizada e impune" (SILVA, 2013, p. 212). É seletiva porque busca atingir dirigentes sindicais, sacerdotes, advogados trabalhistas e líderes que apoiam os camponeses. É institucionalizada porque cria grupos paramilitares em diversos Estados. E é impune porque nos últimos 26 anos houve 1.630 assassinatos por questões de terra, mas apenas 22 casos resultaram em julgamento, sendo que apenas 14 deles terminaram com condenação.

O caso de Eldorado dos Carajás pode ser considerado extremo no uso da violência do Estado perante os trabalhadores no campo no país. Contudo, é importante ressaltar que não é um caso exemplar e nem único no Brasil. As ocupações e os assentamentos no território nacional sofreram com a opção

\footnotetext{
${ }^{30}$ Diário da Câmara dos Deputados. Ano LI, no. 69, 20/4/1996, p. 10375.

${ }^{31}$ Diário da Câmara dos Deputados. Ano LI, nº. 69, 20/4/1996, p. 10375.

${ }^{32}$ Diário da Câmara dos Deputados. Ano LI, nº. 69, 20/4/1996, p. 10377.

${ }^{33}$ Diário da Câmara dos Deputados. Ano LI, no $\mathrm{n}^{\circ}$. 69, 20/4/1996, p. 10377. Para uma análise das características da
} violência no campo ver (BRUMER \& SANTOS, 2006, p. 62-63). 
militar do Executivo para solucionar os problemas da terra. Carajás merece uma relevante consideração: no argumento dos parlamentares governistas, que optaram por direcionar a culpa do ocorrido para os manifestantes - com paus e pedras - e para o Partido dos Trabalhadores. Em nenhum momento, Edinho Bez ou Agnaldo Timóteo questionaram o uso militar e a criminalização dos movimentos sociais que foi colocada em prática pelo Governo Federal.

Ao contrário, os parlamentares petistas demonstraram a opção de criminalizar os movimentos sociais por meio do uso da força policial, o uso do INCRA como braço institucional da violência e o uso da Justiça para omitir a impunidade das chacinas no país. Ao acrescentar o INCRA e a Justiça nos discursos sobre os casos de violência no campo brasileiro, os deputados federais do Partido dos Trabalhadores argumentaram como o Estado estava se fortalecendo para combater qualquer proposta de reforma agrária. $\mathrm{O}$ aparato institucional do Estado brasileiro no uso da violência seletiva e impune foi à forma encontrada para expressão a não solução da questão da terra no país, e o caso de Eldorado dos Carajás foi fundamental para explicitar como juízes, governistas e políticos não se importaram com o método autoritário da violência diante dos trabalhadores rurais sem terra.

\section{Atuação parlamentar e orientações partidárias: as} ideias e a prática política sobre a reforma agrária entre o PT e os deputados federais

A análise da atuação parlamentar e das orientações partidárias precisa ser realizada com a finalidade de avaliar a atuação dos deputados federais perante o partido. As propostas apresentadas na Câmara dos Deputados definidas e defendidas no plenário foram: reforma agrária ampla e massiva para solucionar os problemas do país, desapropriação dos latifúndios improdutivos, disponibilidade para o diálogo com atores sociais e a importância do Programa Especial de Crédito para a Reforma Agrária (Procera).

As propostas partidárias definidas foram: no ano de $1981 \mathrm{com}$ a defesa do sindicalismo rural e da união entre as reivindicações do campo e da cidade brasileira; no ano de 1984, o complemento da reforma agrária por meio do fornecimento de créditos; no ano de 1990, a socialização das empresas agroindustriais e o desenvolvimento de cooperativas de pequenos produtores; no ano de 1993, o apoio as ocupações, a viabilidade dos assentamentos e a possibilidade de formar novas empresas rurais, geridas pelos próprios trabalhadores; no ano de 1994, levaria a vitória de Lula na eleição presidencial, por meio de projetos, de prazos, de metas e de números palpáveis; e no ano de 1995, o partido deveria traduzir a sua proposta de reforma agrária em ações partidárias concretas e permanentes, que constam nas Resoluções de Encontros e Congressos do Partido dos Trabalhadores publicadas no ano de 1998.

Assim, há compatibilidade entre as propostas partidárias e parlamentares no critério: importância do Procera (proposta parlamentar) e fornecimento de crédito (proposta partidária). Em itens como reforma agrária ampla e massiva (proposta parlamentar) e a defesa do sindicalismo rural e da união entre as reivindicações do campo e da cidade brasileira, a socialização das empresas agroindustriais e o desenvolvimento de cooperativas de pequenos produtores, o apoio as ocupações, a viabilidade dos assentamentos e a possibilidade de formar novas empresas rurais, geridas pelos próprios trabalhadores (propostas partidárias) percebe-se que o partido conseguiu definir conceitualmente como fazer a reforma agrária, o que os parlamentares não fizeram na prática. Em itens como disponibilidade para o diálogo (proposta parlamentar), houve a abertura da possibilidade de negociação como método de ação política, o que pode ser entendido como a tradução das ações concretas e permanentes (proposta partidária).

Enfim, verificou-se como o parlamentar atuou com autonomia, ao propor temas além das orientações partidárias como a abertura para negociação e efetivou a proposta partidária como o apoio ao crédito direcionado para a reforma agrária. Concomitantemente, o partido propôs conceitualmente como fazer a reforma agrária que, no plenário da Câmara dos Deputados se restringiu as desapropriações de terras improdutivas e ao repasse de crédito para a compra de terras pelo Governo Federal. Os discursos dos deputados federais Adão Pretto, Fernando Ferro, Paulo Paim e Paulo Rocha mostraram como a temática da reforma agrária foi importante para demarcá-los como atores políticos importantes por meio da crítica incessante a criminalização dos movimentos sociais utilizada pelos Governos Federais na década de 1990 e as omissões estatais diante dos problemas da terra. As múltiplas propostas partidárias não foram prejudicadas por não serem colocadas em prática, isso representou a autonomia parlamentar para propor soluções as situações vivenciadas no cotidiano dos trabalhadores rurais sem terra entre os anos de 1990 e 1998.

\section{Considerações finais}


A luta dos deputados federais do Partido dos Trabalhadores na década de 1990 pode ser dividida em duas etapas. A primeira, até 1995, estes ressaltaram as omissões do Estado brasileiro por meio da violência provocada pela UDR; das relações promíscuas com multinacionais, grandes empresários, usineiros e banqueiros; do discurso vazio e pouco prático sobre o tema reforma agrária; e do não reconhecimento dos movimentos sociais e uso de força policial, principalmente no caso de Corumbiara. As omissões acima foram ressaltadas pelos parlamentares petistas como um descaso do Executivo em solucionar a problemática da terra. A solução proposta pelos parlamentares foi uma reforma agrária ampla e massiva por meio da desapropriação de latifúndios improdutivos e por meio da negociação com a Igreja, os parlamentares, as famílias assentadas e os donos da terra.

Assim, os quatro atores políticos do PT na Câmara dos Deputados propuseram a reforma agrária no país por meio da negociação, critério político definido pelo partido no início da década de 1990 e que foi colocado em prática nas lutas institucionais. Ao envolver importantes atores sociais que foram atingidos pela reforma agrária, ao propor a desapropriação e uma reforma agrária ampla e massiva, os parlamentares petistas mostraram a possibilidade de - concretamente - solucionar os problemas da terra.

Ainda assim, a crítica era importante para ressaltar o modo como o Executivo estava conduzindo a reforma agrária no país na década de 1990. Ao utilizar a força policial diante dos movimentos sociais, o Governo Federal mostrou a intolerância no diálogo e o uso autoritário do aparato militar na criminalização dos movimentos sociais. Ao ignorar o uso da violência por parte da UDR, o Executivo mostrou o descaso com as vidas dos trabalhadores rurais sem terra. Ao usar de um discurso vazio e pouco efetivo sobre a reforma agrária, os governistas mostraram que - na prática nada seria feito pela resolução do problema da terra, principalmente porque as relações com as multinacionais, os grandes empresários, os usineiros e os banqueiros seriam afetadas caso se iniciasse a desapropriação ou a compra da terra por parte do Governo Federal no país.

A segunda etapa, entendida entre os anos de 1996 e 1998, mostrou como o Governo Federal tentou se desvencilhar da problemática da reforma agrária no país, com a venda mais barata da terra, o não repasse de recursos para a infraestrutura em assentamentos, a cobrança de dívidas aos pequenos e médios agricultores, as propostas de reforma agrária que não envolveria terras invadidas. Os métodos governistas demonstraram como a terra não era e nem se transformaria em uma dificuldade nas relações políticas com grandes proprietários e empresários agrícolas e agrários no país, nada colocaria em questão a opção do Governo Federal por ignorar as reivindicações dos movimentos sociais do campo e optar pelo apoio de atores sociais que tem a posse da terra no Brasil.

Os parlamentares petistas ressaltaram que as condições para efetivar a reforma agrária eram o aumento do crédito do Programa Especial de Crédito para a Reforma Agrária (Procera) e a desapropriação de terras improdutivas no país. A existência do crédito para a reforma agrária mostrou que há a possibilidade da compra da terra pelo Governo Federal no país; há possibilidade de desapropriar terras improdutivas que se enquadrem nos critérios de agressão ao meio ambiente, de uso do trabalho escravo e de uso para plantar substâncias psicotrópicas; e a opção desenvolvimentista do Movimento dos Trabalhadores Rurais Sem Terra mostrou como deve ser iniciada a reforma agrária: pela pequena propriedade que inclua pequenos $\mathrm{e}$ médios proprietários com o financiamento e a assistência técnica necessária para capacitar e fixar os trabalhadores no campo.

A transformação das reivindicações pela reforma agrária em reivindicações políticas por parte do Governo Federal representou os métodos governistas para criminalizar a legitimidade dos movimentos rurais que tiveram a reforma agrária como bandeira de luta política e social. As omissões das instituições estatais no direcionamento político da reforma agrária e da existência da violência no campo brasileiro mostraram a prioridade neoliberal para o grande capital na questão agrária e o descaso da temática da terra no o país.

\section{Referências}

ABRAMOVAY, Ricardo Abramovay. Agricultura familiar e capitalismo no campo. In: STÉDILE, João Pedro (org.). A questão agrária no Brasil: o debate na década de 1990. São Paulo, Expressão Popular, 2013. pp. 111-122.

ALBUQUERQUE JÚNIOR, Durval Muniz de. Discursos e pronunciamentos. A dimensão retórica da historiografia. In: PINSKY, Carla \& LUCA, Tânia de (org.). O historiador e suas fontes. São Paulo, Contexto, 2009. pp. 223-249.

BRUMER, Anita; SANTOS, José Vicente Tavares dos. Estudos agrários no Brasil: modernização, violência e lutas sociais (desenvolvimento e limites 
da Sociologia Rural no final do século XX). NERA, Presidente Prudente, 9, pp. 49-72, jul-dez. 2006.

FERNANDES, Bernardo Mançano. A formação do MST no Brasil. Petrópolis: Vozes, 2000.

GROS, Denise Barbosa. Institutos liberais e neoliberalismo no Brasil da Nova República. Porto Alegre, Fundação de Economia e Estatística Siegfried Emanuel Heuser, 2003.

KUSCHNIR, Karina. O cotidiano da política. Rio de Janeiro, Jorge Zahar Ed, 2000.

LEAL, Paulo Roberto Figueira. O PT e o dilema da representação política: os deputados federais são representantes de quem? Rio de Janeiro, FGV, 2005.

MELO, Ana Lúcia Aguiar. A ação política do Partido dos Trabalhadores e a busca do equilíbrio. Revista do Centro de Ciências Sociais e Humanas, Universidade Federal de Santa Maria, Santa Maria - RS, v. 11, n. 2, p. 4760. 1998.

OLIVEIRA, Ariovaldo Umbelino de. O campo brasileiro no final dos anos 1980. In João Pedro Stédile (org.), A questão agrária no Brasil: o debate na década de 1990. São Paulo, Expressão Popular, 2013. pp. 55-80.

POCOCK, John G.A. Linguagens do ideário político. São Paulo, EDUSP, 2003.

RANINCHESKI, Sônia; CORDEIRO, Nathália R. (2008), “Democracia processual ou participativa: a visão do PSDB e PT na câmara dos deputados do Brasil". Debates, v. 2, pp. 213-244. 2008.

Resoluções de Encontros e Congressos. São Paulo, Editora Fundação Perseu Abramo, 1998.
SAUER, Sérgio. 'Reforma agrária de mercado' no Brasil: um sonho que se tornou dívida. Estudos Sociedade e Agricultura, Rio de Janeiro, v. 18, n. 1, pp. 98-126. 2010.

SILVA, José Gomes da. A reforma agrária no Brasil. In: STÉDILE, João Pedro (org.). A questão agrária no Brasil: o debate na década de 1990. São Paulo, Expressão Popular, 2013. pp. 197-224.

STÉDILE, João Pedro. A questão agrária e o socialismo. In: STÉDILE, João Pedro (org.). A questão agrária no Brasil: o debate na década de 1990. São Paulo, Expressão Popular, 2013. pp. 365-384.

VEIGA, José Eli da Veiga. Fundamentos do agrorreformismo. In: STÉDILE, João Pedro (org.). A questão agrária no Brasil: o debate na década de 1990. São Paulo, Expressão Popular, 2013. pp. 81-110.

VIEIRA, Vera Lúcia Vieira. Criminalização das lutas sociais em estados autocráticos burgueses. Projeto História, São Paulo, v. 31, p. 189-205, dez. 2005

WEBER, Max. Ciência e política: duas vocações. $13^{a}$ edição. São Paulo, Cultrix. 2005. 